\title{
PATTERN OF STUDENTS' ENROLMENT AND GRADUATION RATES IN AL-HIKMAH UNIVERSITY, NIGERIA: IMPLICATIONS FOR MANAGEMENT
}

\author{
YUSUF SULEIMAN ${ }^{1}$ \\ Department of Educational Management and Counselling, Faculty of Education, \\ Al-Hikmah University
}

MUSTAPHA ADAM ISHOLA

Department of Educational Management, Faculty of Education, University of Ilorin

ADEDOKUN AFEEZ DEWUNMI

Centre for Research, Industrial Linkage and International Cooperation, Al-Hikmah University

\author{
ABDULQODIR AMINAH ABIOLA \\ Centre for Research, Industrial Linkage and International Cooperation, \\ Al-Hikmah University
}

\begin{abstract}
Enrolment and graduation rates are regarded as important indices that can be used to measure the growth and development of higher institutions, be it private or public. It is on this premise that this study assessed the students' enrolment and graduation rates in Al-Hikmah University and its implication for the management. Two research questions were raised to guide the study. In order to provide answers to the research questions, secondary data were collected that consists of number of students' enrolment from 2006-2019. Also, number of students that graduated were obtained from 2009-2019. Data collected were analysed using descriptive method. Findings of the study revealed high students' enrolment from 2006 to 2020. Specifically, the highest enrolment in the university was in 2019 where it had 2793 at undergraduate level while 288 students were admitted in the year 2020 at postgraduate level. On graduation rate, findings showed that in the 2015/2016, 874 students graduated from the university, been the highest number of graduands ever recorded at undergraduate level while 64 postgraduate students were graduated in the year 2017/2018 session, been the highest number since the inception of the university. Based on the foregoing, the study concludes that enrolment and graduation rates are key determinants of school success. The study recommends
\end{abstract}

1 Contact: Yusuf Suleiman, yusufsuleiman@alhikmah.edu.ng, Department of Educational Management and Counselling, Faculty of Education, Al-Hikmah University, Ilorin, Kwara State, Nigeria. 
that there is need for recruitment of agents to assist the university in sourcing for students that are yearning for admission. The agents to be recruited must be remunerated based on number of students they bring to the university; this will increase their recruitment drive. Lastly, there is need for downward review of the school fees so as to increase the enrolment of students.

Keywords: Nigeria, Enrolment, Graduation, Student, University System

\section{INTRODUCTION}

Education is an essential instrument in the society which aids individual development and the nation as a whole, thus calls for the involvement of public and private sectors as a result of the substantial resources required for its effective delivery and acquisition. This germane sector was placed under concurrent legislative in the post independent Nigerian constitution and virtually left to the then regional government, while the Federal Government enacted laws on policy matters. Actualisation of qualitative education hinges on adequate provision of educational facilities such as effectively equipped library, good conducive classroom environment and a well-structured building which consequently enhance the enrolment and graduation rates of students. This calls for optimal utilisation of vast resources within the framework of the set educational objectives (Harry, 2019; Ihugba, Ukwunna \& Sandralyn, 2019; Omodero \& Nwangwa, 2020). Education as an input, process and output system, required a watchful analysis with a view to take decisions that have implications on future education development. Education as an open system encompasses flow of resources into, within and outside the system, thus educational planners need vital information for effective and efficient plan of the future growth of the national, state and local government levels. It is becoming increasingly obvious in higher institution in Nigeria that their future survival as an educational entity depends to a large extent on the efficient management of available resources (Ayodele, 2016; Olaniyonu, 2016; Oyesola, 2000).

Clark (2013) emphasised that the number of students at the tertiary level has grown from 15,000 in 1970 to over 1.2 million today. As a result of enormous surge in demand, hundreds of thousands of aspiring tertiary students are annually missing out on places due to inadequate spaces to meet the demand. In 2013, 1.7million students registered for Nigeria's centralised tertiary admission examinations conducted by Joint Admission and Matriculation Board JAMB, all competing for the half million places available; potentially leaving over a million qualified college-age Nigerians without a post-secondary place. Rukayat (2019) opined that the rising number of students who enrol for admission into tertiary institutions yearly is worrying, as revealed through the number of students sitting for the year 2019 entrance examination into tertiary institutions which could only accommodated one-third of the applicants, the remaining candidates, who may even pass the admission cut-off mark, may never get admitted. Universities in Nigeria account for 5.31 percent of the total enrolment in Nigerian universities 
which is unhealthy and the need for more access either by creating more universities or expanding the existing ones. The country population close to 200 million, while the enrolment into universities slightly less than two million which translate to roughly 1 percent of the population. It is evident that Nigerian government has not been able to meet the huge demand of education despite the proliferation of private universities.

The issue of students' enrolment and graduation in university education especially the privately owned institutions of higher learning has raised deep concern among scholars, universities administrators and planners, as well as relevant stakeholders in educational industry in Nigeria. Different factors have been identified as capable of influencing graduation and enrolment of students in the Nigerian Universities ranging from the school library, school building, unconducive classroom environment and the school laboratory (Ileuma, 2015). The fundamental focus of tertiary institution is optimal utilisation of limited available resources through effective and efficient running of the system, proper upkeep of the structural units and facilities, functional school building and effective conveyance of the school's curriculum which positively enhance students 'enrolment and graduation (Ogbodo \& Onyene, 2015). It is increasingly becoming understandable in institutions of higher learning in Nigeria that their future survival as educational entity depend to a great degree on the efficient management of available educational resources like: building, classrooms and office infrastructures, equipment, library, hostel, blackboard and school records. Its material conditions should be conductive for all - round development of the student - physical, emotional, social, cultural and moral (Stickhard \& Mayberry, 2016).

Pleasant school setting creates an optimal setting high enrolment. The school is a stabilising force for young people, both emotionally and academically particularly when they are experiencing transition or crises (Robert Blum, 2005). Educational facilities such as school plant have been repeatedly found to have positive relationship with standard and quality of educational system (Nwagwu, 2014: Adesina, 2016 \& Ojedele, 2018). The school enrolments are rapidly expanding in the state where equipment and facilities are demanding to supply in adequate quantities. There is paucity of fund to procure new paraphernalia and facilities despite the fact that some of the existing ones have become overreached and obsolescent. Previous related study had revealed clearly that Nigerian School Managers do not usually take the issue of Educational facilities maintenance seriously. The managerial arrangement typical of the educational system is grossly inadequate to deal with the new challenges in the educational system and this is creating educational crisis (Olutola, 2017).

Expansion and diversification of university education determined by the demand of an upwardly mobile population and the needs of a globalised economy are important factors underlying the rising demand for university education in Nigeria. The major contributing factors on the expansion policy include high population growth, expansion of basic and secondary education and the rising rate of students seeking admission into university education. Many abandoned and 
uncompleted school plant projects apart from many school plants suffering neglects of maintenance in universities in Nigeria. The existing school plants are in pitiable condition of neglect wield negative influence on the public Universities in Nigeria. Therefore, there is need to call for planned and managed school plant in Nigerian universities in order to reduce the high cost of replacement that often result from total breakdown of School Plants due to improper management (Ademola, Ogundipe \& Babatunde, 2014; Musa \& Bichi, 2019; Oviawe, 2017).

Despite the apparently high percentage of the annual budget on education, recently the Federal Government releases over \#3bn through TETFUND, the major constraints to Public universities enrolments are rapidly expanding, while educational facilities and equipment are in the state of paucity and inadequately being supply supplied in proportion (Adesina, 2014).

Furthermore, prior to the advent of the private university in Nigeria in the year 1999, enrolment into tertiary institutions had been on the increase but what is rather disheartening in spite of the Private universities rising rate is the fact that the chances of getting admission into the quality institutions is decreasing by the day. There are many factors influencing prospective candidates, who are thirsting for quality tertiary institutions. The factors range from limited number of quality tertiary institutions, limited teaching facilities, inadequate spaces to handle proportionally with the increasing population of potential students and above all, restricted number of good mentors in the owners of the institutions. In 1999, the development that seemed like a ray of hope for admission seekers occurred when private Universities began to spring up nationwide almost on annual basis. This development to some extent cushions the effect of the acute scarce admission into tertiary institution among the seekers but not totally (Dada, 2017; Ileuma, 2015). Based on the foregoing, therefore, the current study assesses the enrolment and graduation rate of undergraduates and post graduate students of Al-Hikmah University, Nigeria with its implication for management.

\section{LITERATURE REVIEW}

Extensive studies have been conducted on students' enrolment and graduation in educational industry focusing mainly in public institutions. For instance, Ileuma (2015) conducted study on managing educational facilities and students' enrolment in Nigerian Universities in South-west Nigeria. The Study adopted a survey research design of ex-post facto type. The Population of the study comprised 300 participants in which about $50 \%$ of the target population that were sampled. Multi-stage sampling technique was used to get the sample size in South - western Nigeria. A Standardised research instrument titled "Managing Educational Facilities and Students Enrolment Questionnaire" (MEFSEQ) was used to collect relevant date for the study. The content, construct and face validity of the instruments were ascertained by two experts in the field of educational management and foundation and one 
specialist in educational measurement and evaluation, while its reliability co-efficient was established using the test-retest method and the reliability coefficient of 0.84 was obtained which affirmed that the instrument was reliable. Inferential Statistics of Multiple Regression and Pearson Product Moment Correlation Coefficient were used to analyses the hypotheses tested at 0.05 level of Significance. The result revealed that classroom environment is a major determinant of students' enrolment. There was a strong positive significant relationship between the school building and student's enrolment. It was recommended among other that parents should pay adequate attention to their ward's education while the necessary educational facilities should be provided by the school authorities, government as well as the stakeholders to aid students' enrolment, as well as learning activities.

Ademola, Babatunde and Ogundipe (2014) investigated students' enrolment into tertiary institutions in Nigeria: The influence of the proprietors' reputation: A Case Study. The data gathered from the survey was analysed using simplepercentage and demographics such that elements of quantitative analysis was used and the content analysis of the qualitative data was likewise done. The findings of the study showed that increased students' enrolment has a lot to do with reputation of the proprietors, ability and experience of the founder and the facilities they have created including of the founder/proprietor. Thus, increased students' enrolment has a lot to do with reputation, ability and experience of the founder and the facilities they have created including of the founder/proprietor. The key success indicator for measuring learning achievements in any university viz: infrastructure excellence, superb curriculum development and delivery, alignment with requisite government policy, adequate funding, staff/student relationship, quality of human resources revolves around the proprietor of the university whether government, individuals or religious organisations.

The findings of the study conducted by Fabunmi (2016) revealed that classroom conditions and environment positively influence students' enrolment in the Nigerian Universities. Adeogun (2015) conducted study on the nexus between students' enrolment and goal achievement in tertiary institutions in Nigeria. The study employed qualitative approach and the findings revealed that student's enrolment to a larger extent cannot be ignored as a vital determinant for the attainability of university goal. Also, Taiwo, Oyesola, \& Adeogun (2016) examined the relationship between school building and students' enrolment in Private universities in south-west, Nigeria. The findings of the study show that the success of an educational rests on the availability of physical facilities especially the school building. Also, Onasanya and Adegbija (2017) in their study revealed that well sited school buildings with aesthetic conditions, playground, lavatory and facilities significantly enhance students' enrolment and graduation in higher educational institutions. Apart from not presenting a conducive environment for enrolment, they are dearth trap for children whose lives are put at risks in fact that have been cases where students lost their lives and some get seriously injured as a result of collapse of school buildings. 
Fabunmi (2016) conducted comparative study between universities in developing countries and advanced countries and effects on students' enrolment. The study showed that good facilities appear to be an important preoccupation for students' enrolment, provided that other conditions are present that support a strong academic programme in the school. A growing body of research has linked students' enrolment and behaviours to the physical building conditions and overcrowding. Todd (2003) took a different approach in an Ohio study that it was found that the school population increased by $52.5 \%$ as majority of the students rated the library as "Most resourceful" quite helpful in getting better grades in projects and assignments. This suggests that students themselves endorse the idea that good school libraries have impact on enrolment.

The work of Enagbonma and Osagiede (2018) focused on a model for estimating the number of academic staff for in Nigerian universities and established that increase in the number of academic staff is necessary for the development of universities. Omitogun, Akanni, Longe and Balogun (2017) examined the relationship between government expenditure and education enrolment in Nigerian schools. The study found that high expenditure is a predictor of high enrolment in education system. The concluded that more fund should be allocated to education for the overall development. Oviawe (2017) assessed students' enrolment in technical education programmes in Nigeria and found that high enrolment is an indicator of students' involvement in technical education programmes.

\section{RESEARCH QUESTIONS}

1. What is the students' enrolment rate in Al-Hikmah University?

2. What is the students' graduation rate in Al-Hikmah University?

\section{METHODOLOGY}

In order to provide response to the two research questions generated for the study, secondary data were collected from the Registry Unit and Students' Affairs Unit of the university. Specifically, the data collected from Students' Affairs Unit was based on students' enrolment in the university since inception. In the same vein, data collected obtained from the Registry Unit of the University was based on student graduation. The coverage of the data collected is shown below:

Table 1

Data Collected on Students' Enrolment and Graduation Rate

\begin{tabular}{|l|l|c|}
\hline S/N & \multicolumn{1}{|c|}{ Data Collected } & Year Covered \\
\hline 1 & Number of Undergraduate Students' Enrolment Rate & $2006-2019$ \\
\hline 2 & Number of Postgraduate Students' Enrolment Rate & $2014-2020$ \\
\hline 3 & Number of Undergraduate Students' Graduation Rate & $2009-2018$ \\
\hline 4 & Number of Postgraduate Graduations' Rate & $2015-2019$ \\
\hline
\end{tabular}


106 PATTERN OF STUDENTS' ENROLMENT AND GRADUATION RATES ..

Data collected were analysed using descriptive method to understand the flow of students' enrolment as well as graduation rates in Al-Hikmah University, Nigeria.

\section{ANALYSIS}

Research Question One: What is the students' ENROLMENT RATE IN AL-HIKMAH UNIVERSITY?

Table Showing the Number of Undergraduate Enrolments (2006-2019)

\begin{tabular}{|l|c|c|}
\hline \multicolumn{1}{|c|}{ Year } & Number of Enrolments & Percentage (\%) \\
\hline 2006 & 70 & 0.57 \\
\hline 2007 & 148 & 1.22 \\
\hline 2008 & 340 & 2.80 \\
\hline 2009 & 425 & 3.50 \\
\hline 2010 & 520 & 4.29 \\
\hline 2011 & 649 & 5.35 \\
\hline 2012 & 883 & 7.28 \\
\hline 2013 & 1630 & 13.43 \\
\hline 2014 & 1125 & 9.27 \\
\hline 2015 & 993 & 8.18 \\
\hline 2016 & 1017 & 8.38 \\
\hline 2017 & 690 & 5.69 \\
\hline 2018 & 851 & 7.01 \\
\hline 2019 & 2793 & 23.02 \\
\hline Total & $\mathbf{1 2 1 3 4}$ & \\
\hline
\end{tabular}

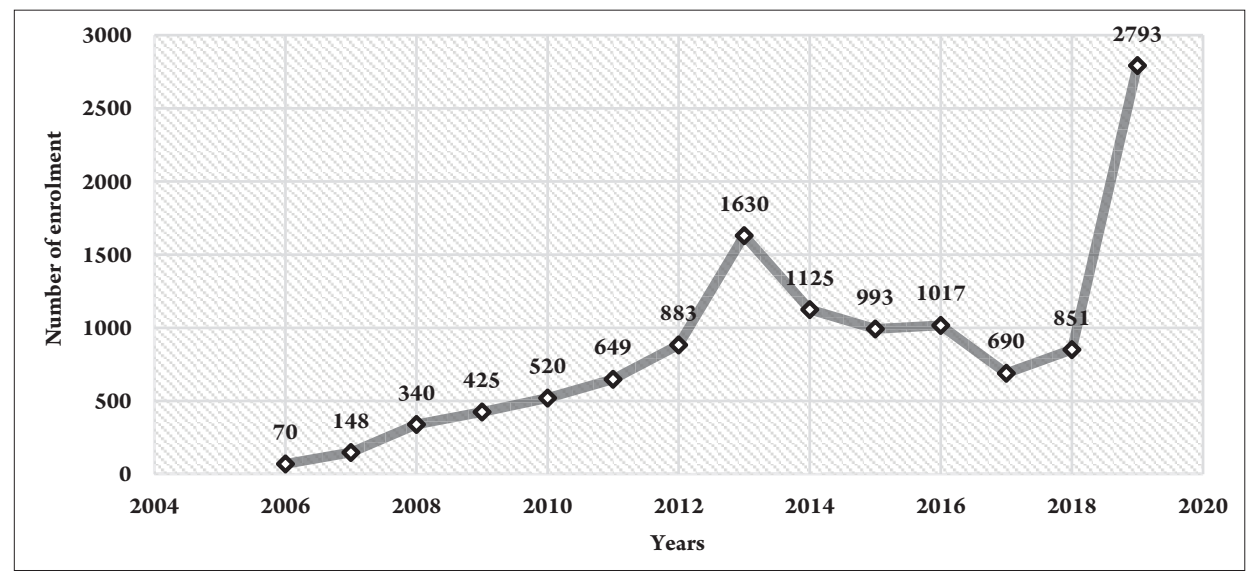

Figure 1. Line graph showing the trend of the number of undergraduate enrolments from 2006-2019 
The enrolment rate of the students to Al-Hikmah University from day one (2006-2019) is shown in the table and chart above. It can be seen that 70 students were enrolled into the University in the year 2006 while 148 students were registered in 2007. There was a drastic shift in the enrolment rate in the year 2008 where 340 students were admitted into the University for several courses while 425 students were as well enrolled in the year 2009. 520 students were admitted in the year 2010 while 649 students were enrolled for 2011 academic session. In the year 2012, 883 students were admitted into the University. A paradigm shift occurred in the year 2013 where 1,630 students were admitted into the University. Meanwhile, in the year 2014, there was a drop in the number of admitted students where 1,125 were enrolled and 993 of the students in the year 2015. 1017 students were enrolled in the year 2016. There was a drop in the year 2017 with 690 students admitted while 851 students were enrolled in the year 2018 and in 2019, the number of students enrolled rose drastically which account for 2793 students. Finally, it can be seen that the University had the least number of students enrolled in 2006 as a result of it being the year of her inception and has the highest number of students enrolled in 2019 and still counting.

Table 3

Table Showing the Number of Admitted Postgraduate Students (2014-2020)

\begin{tabular}{|l|c|c|}
\hline \multicolumn{1}{|c|}{ Session } & Number of Admitted Students & Percentage (\%) \\
\hline $2014 / 2015$ & 55 & 8 \\
\hline $2015 / 2016$ & 50 & 8 \\
\hline $2016 / 2017$ & 43 & 6 \\
\hline $2017 / 2018$ & 72 & 11 \\
\hline $2018 / 2019$ & 159 & 24 \\
\hline $2019 / 2020$ & 288 & 43 \\
\hline Total & $\mathbf{6 6 7}$ & $\mathbf{1 0 0}$ \\
\hline
\end{tabular}

The table above shows the number of admitted postgraduate students from 2014-2020. It can be seen that there are a total of 667 students for the 6 years. In 2014/2015, 55 students were admitted into the postgraduate school which accounts for $8 \%$. Also, 50 students were enrolled in 2015/2016 and 43 students in the year 2016/2017 academic session which account for $8 \%$ and $6 \%$ respectively. For the 2017/2018 academic session, 72 students were admitted and this accounts for $11 \%$ while 159 (24\%) students were also admitted in the 2018/2019 academic session and 288 (43\%) students were admitted for the 2019/2020 academic session. Finally, 2016/2017 has the least number of admitted students as compared with other sessions with 2019/2020 having the highest number of admitted postgraduate students. The figure below indicates the trend in number of admitted postgraduate students: 


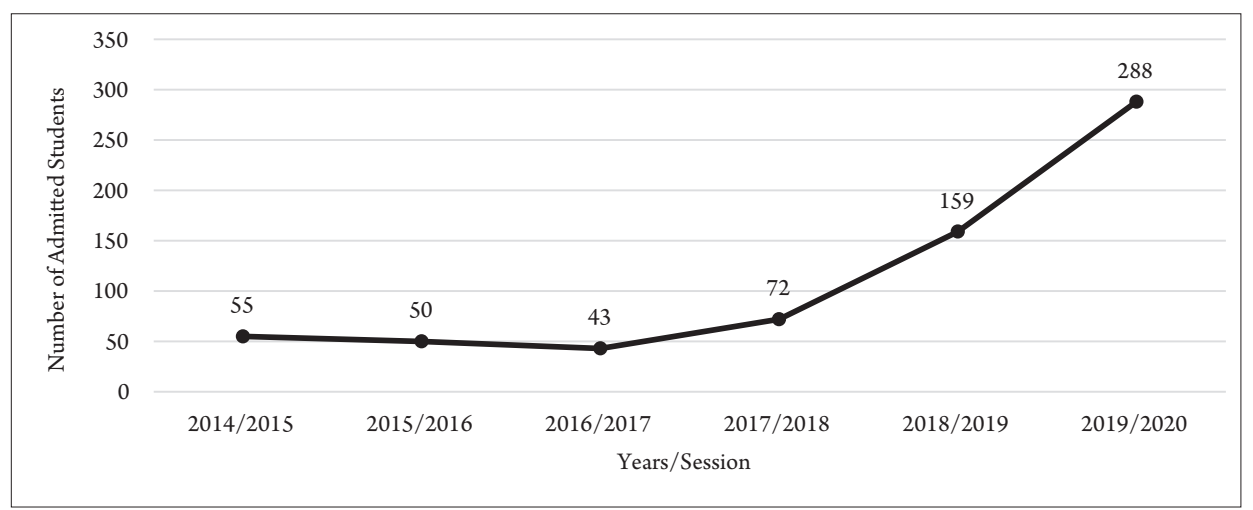

Figure 2. Line graph showing the number of admitted postgraduate students (2014-2020)

The above line graph shows the number of admitted postgraduate students for a period of 6 years (2014-2020). It can be seen that 55 students were admitted in 2014/2015 academic session and there was a decrease in 2015/2016 and 2016/2017 as 50 and 43 students were admitted respectively. In 2017/2018, there was an increase in the enrolment rate as a total of 72 students were admitted for that academic year. In 2018/2019, there was a drastic increase as the enrolment rose from 73 to 159 and also rose from 159 students in 2018/2019 to 288 students in 2019/2020 and still counting. So far, 2019/2020 has the highest number of admitted postgraduate students with 2016/2017 having the least.

Table 4

Table Showing the Number of Admitted Postgraduate Students by Programme

\begin{tabular}{|l|c|c|c|c|c|c|}
\hline \multicolumn{1}{|c|}{ Programme } & $\begin{array}{c}\mathbf{2 0 1 4} / \\
\mathbf{2 0 1 5}\end{array}$ & $\begin{array}{c}\mathbf{2 0 1 5} / \\
\mathbf{2 0 1 6}\end{array}$ & $\begin{array}{c}\mathbf{2 0 1 6 /} \\
\mathbf{2 0 1 7}\end{array}$ & $\begin{array}{c}\mathbf{2 0 1 7} / \\
\mathbf{2 0 1 8}\end{array}$ & $\begin{array}{c}\mathbf{2 0 1 8} / \\
\mathbf{2 0 1 9}\end{array}$ & $\begin{array}{c}\mathbf{2 0 1 9} \\
\mathbf{2 0 2 0}\end{array}$ \\
\hline M.A Arabic & 16 & 23 & 13 & 20 & 26 & 17 \\
\hline M.A Islamic Studies & 39 & 27 & 30 & 30 & 35 & 35 \\
\hline M.A History & 0 & 0 & 0 & 0 & 4 & 9 \\
\hline M.A English & 0 & 0 & 0 & 0 & 7 & 15 \\
\hline M.Ed. Islamic Studies & 0 & 0 & 0 & 0 & 6 & 11 \\
\hline M.Ed. Educational Management & 0 & 0 & 0 & 0 & 19 & 19 \\
\hline M.Ed. Arabic & 0 & 0 & 0 & 0 & 0 & 3 \\
\hline M.Ed. Guidance \& Counselling & 0 & 0 & 0 & 0 & 0 & 8 \\
\hline M.Sc. Business Administration & 0 & 0 & 0 & 0 & 0 & 8 \\
\hline M.Sc. Economics & 0 & 0 & 0 & 0 & 0 & 4 \\
\hline M.Sc. Accounting & 0 & 0 & 0 & 0 & 0 & 6 \\
\hline M.Sc. Finance & 0 & 0 & 0 & 0 & 0 & 1 \\
\hline M.Sc. Statistics & 0 & 0 & 0 & 0 & 0 & 2 \\
\hline M.Sc. Geology & 0 & 0 & 0 & 0 & 0 & 1 \\
\hline
\end{tabular}




\begin{tabular}{|l|c|c|c|c|c|c|}
\hline \multicolumn{1}{|c|}{ Programme } & $\mathbf{2 0 1 4 /}$ & $\mathbf{2 0 1 5 /}$ & $\mathbf{2 0 1 6 /}$ & $\mathbf{2 0 1 7 /}$ & $\mathbf{2 0 1 8 /}$ & $\mathbf{2 0 1 9 /}$ \\
& $\mathbf{2 0 1 5}$ & $\mathbf{2 0 1 6}$ & $\mathbf{2 0 1 7}$ & $\mathbf{2 0 1 8}$ & $\mathbf{2 0 1 9}$ & $\mathbf{2 0 2 0}$ \\
\hline M.Sc. Biochemistry & 0 & 0 & 0 & 0 & 0 & 4 \\
\hline M.Sc. Computer Science & 0 & 0 & 0 & 0 & 0 & 7 \\
\hline M.Sc. Mass Communication & 0 & 0 & 0 & 0 & 0 & 4 \\
\hline M.Phil/Ph.D. Arabic & 0 & 0 & 0 & 0 & 3 & 1 \\
\hline M.Phil/Ph.D. Islamic Studies & 0 & 0 & 0 & 0 & 7 & 6 \\
\hline M.Phil/Ph.D Educational Mgt & 0 & 0 & 0 & 0 & 0 & 4 \\
\hline M.Phil/Ph.D Geology & 0 & 0 & 0 & 0 & 0 & 2 \\
\hline PGDE & 0 & 0 & 0 & 22 & 19 & 92 \\
\hline PGDE Educational Management & 0 & 0 & 0 & 0 & 0 & 5 \\
\hline PGD Public Health & 0 & 0 & 0 & 0 & 0 & 6 \\
\hline PGDE Strategic Management & 0 & 0 & 0 & 0 & 0 & 2 \\
\hline Ph.D Arabic & 0 & 0 & 0 & 0 & 17 & 8 \\
\hline Ph.D Islamic Studies & 0 & 0 & 0 & 0 & 16 & 6 \\
\hline Ph.D Statistics & 0 & 0 & 0 & 0 & 0 & 2 \\
\hline Total & $\mathbf{5 5}$ & $\mathbf{5 0}$ & $\mathbf{4 3}$ & $\mathbf{7 2}$ & $\mathbf{1 5 9}$ & $\mathbf{2 8 8}$ \\
\hline
\end{tabular}

The table above shows the number of admitted postgraduate students by the type of programme for the period of 2014-2020. It can be that in 2014/205, only two programmes was available to the 55 admitted students, that is, 16 and 39 students were admitted into Masters of Arts in Arabic and Islamic Studies respectively. Also, in 2015/2016 and 2016/2017 academic session, Masters of Arts in Arabic and Islamic Studies still remain the two programme available, and 50 (23 students for Arabic and 27 for Islamic Studies) and 43 (13 students for Arabic and 30 for Islamic Studies ) students were admitted respectively. In 2017/2018, there was an inclusion of Postgraduate Diploma in Education (PGDE) to the two existing programmes and a total of 72 students were admitted with 20, 30 and 22 students for the programme of Masters of Art in Arabic, Islamic Studies and PGDE respectively.

For the 2018/2019 academic session, 8 other programmes were introduced and totalling 11 programmes available for that session. The 8 other programmes are M.Phil/PhD Arabic with 3 students, M.Phil/PhD Islamic Studies with 7 students, PhD Arabic with 17 students, PhD Islamic Studies with 16 students, Masters of Arts in History with 4 students, Masters of Arts in English with 7 students, Masters of Education in Islamic Studies with 6 students and Masters of Education in Educational Management with 19 students. There are 26, 35 and 19 students admitted for Masters of Arts in Arabic, Islamic Studies and PGDE respectively. Seventeen (17) other programmes were later introduced in 2019/2020 academic session which makes a total of 28 programmes in all. The seventeen (17) programmes are: Master of Science in Mass Communication with 4 students, Master of Science in Business Administration with 8 students, Master of Science in Economics with 4 students, Master of Science in Accounting with 6 students, Master of Science in Finance with 1 student, Master of Science 
in Statistics with 2 students, Master of Science in Computer Science with 7 students, Master of Science in Geology with 1 student, Master of Science in Biochemistry with 4 students, M.Phil/PhD Geology with 2 students, Masters of Education in Guidance \& Counselling with 8 students, M.Phil/PhD in Educational Management with 4 students, PhD Statistics with 2 students, PGDE in Educational Management with 5 students, PGDE in Strategic Management with 2 students, PGD in public Health with 6 students and Masters of Education in Arabic with 3 students. The 11 existing programmes; M.Phil/PhD Arabic with 1 student, M.Phil/PhD Islamic Studies with 6 students, PhD Arabic with 8 students, PhD Islamic Studies with 6 students, Masters of Arts in History with 9 students, Masters of Arts in English with 15 students, Masters of Education in Islamic Studies with 11 students and Masters of Education in Educational Management with 19 students. There are 17, 35 and 92 students admitted for Masters of Arts in Arabic, Islamic Studies and PGDE respectively.

Research Question Two: What is the students' GRADUATION RATE IN Al-HikMAH UNIVERSITY?

Table Showing Undergraduate Graduation Rate from 2009-2018

\begin{tabular}{|l|c|c|}
\hline $\mathbf{S} / \mathbf{N}$ & Year & Graduation Rate \\
\hline 1 & $2009 / 2010$ & 107 \\
\hline 2 & $2010 / 2011$ & 363 \\
\hline 3 & $2011 / 2012$ & 455 \\
\hline 4 & $2012 / 2013$ & 502 \\
\hline 5 & $2013 / 2014$ & 659 \\
\hline 6 & $2014 / 2015$ & 817 \\
\hline 7 & $2015 / 2016$ & 874 \\
\hline 8 & $2016 / 2017$ & 827 \\
\hline 9 & $2017 / 2018$ & 798 \\
\hline
\end{tabular}

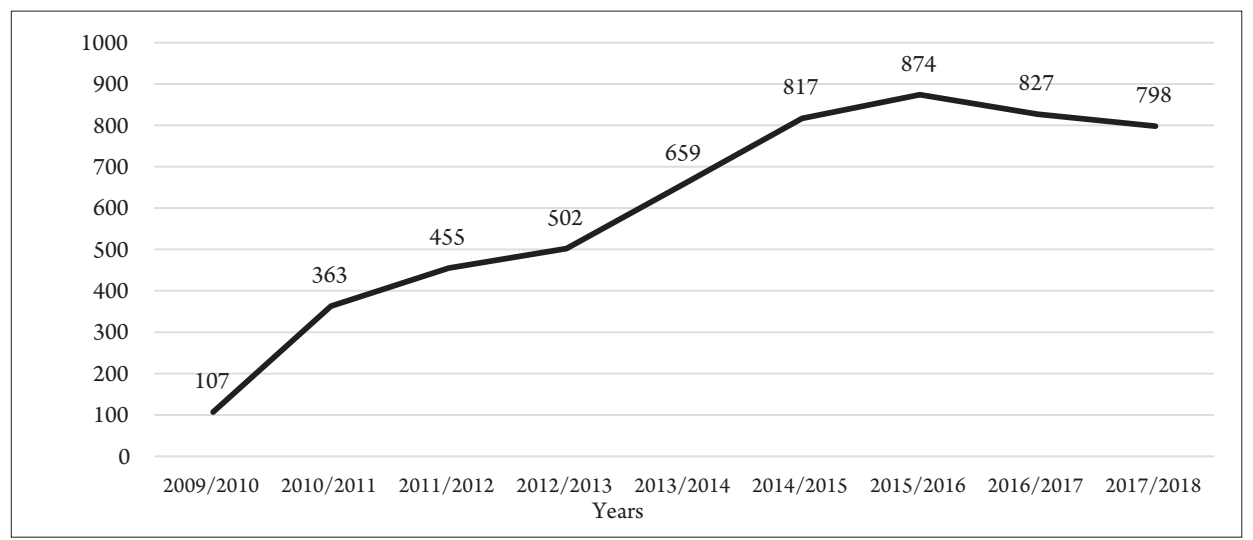

Figure 3. Trend of Undergraduate Graduation Rate from 2009-2018 
The graduation rate of Al-Hikmah University from 2009/2010 to 2017/2018 academic session is shown in the graph above. It can be seen from the above chart that the University produced 107 graduating students in her first convocation ceremony in the year 2010. In 2010/2011, 363 students graduated while 455 students graduated in 2011/2012 academic session. It can also be seen that the graduation rate is increasing as 502 graduated in the following year and also 659 students graduated in 2013/2014 session. This increment improved drastically as 817 and 874 students graduated in 2014/2015 and 2015/2016 academic session respectively. In 2016/2017, there is a downward trend as the number of the graduating student reduced to 827 students as compared with the preceding year which produced 874 students; this continues till 2017/2018 which also produced 798 graduating students. On a final note, it can be seen that 2009/2010 produced the least number of graduating students with a value of 107 students while 2015/2016 has the highest number of graduating students with a value of 874 students.

Table 6

Table Showing the Number of Graduation Rate at Postgraduate Level

\begin{tabular}{|l|c|}
\hline \multicolumn{1}{|c|}{ Session } & Number of Graduating Students \\
\hline $2014 / 2015$ & 54 \\
\hline $2015 / 2016$ & 50 \\
\hline $2016 / 2017$ & 43 \\
\hline $2017 / 2018$ & 64 \\
\hline $2018 / 2019$ & 19 \\
\hline Total & 230 \\
\hline
\end{tabular}

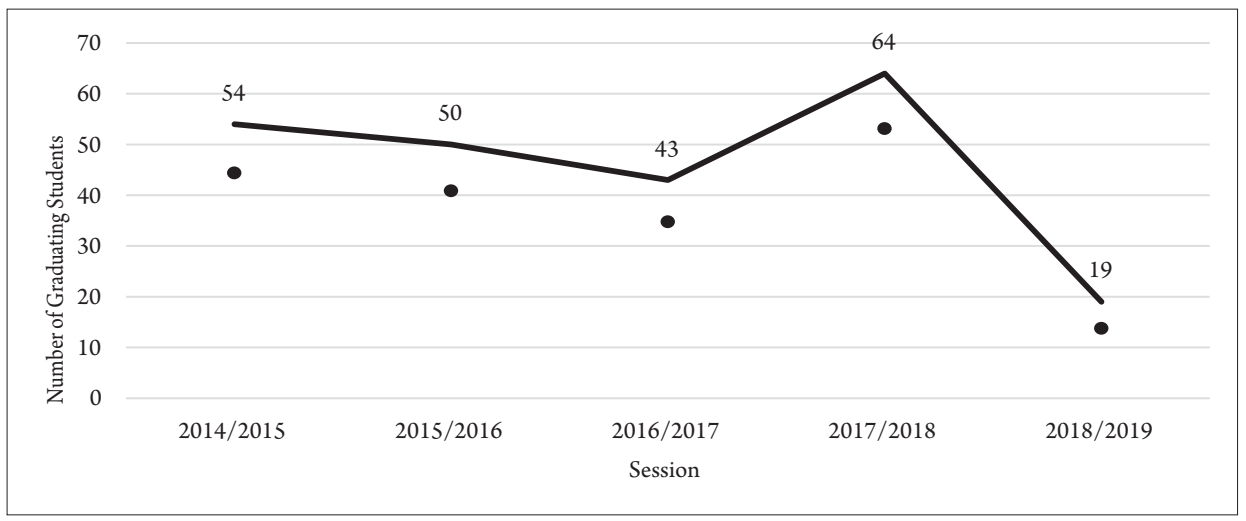

Figure 4. Line Graph Showing the Number of Graduating Postgraduate Students (2014-2019)

From the table and figure above, it can be seen from the above table that 54 students graduated in the 2014/2015 academic session, 50 and 43 students 
graduated in the 2015/2016 and 2016/2017 academic session respectively. 64 and 19 students also graduated in the 2017/2018 and 2018/2019 academic session.

\section{DISCUSSION}

In line with the first research question of the study, which was based on students' enrolment rate in Al-Hikmah University, findings indicate that the university had the least number of undergraduate students enrolled in 2006 as a result of it being the year of her inception and has the highest number of students enrolled in 2019 and still counting. Specifically, the number enrolled in 2006 was 70 students while 2793 were enrolled in 2019. Findings also reveal that at postgraduate level, 2016/2017 has the least number of admitted students as compared with other sessions with 2019/2020 having the highest number of admitted postgraduate students. The current findings are in congruent with the study conducted by Onasanya and Adegbija (2017) who established that conducive learning environment increased students' enrolment in education system. Specifically, aesthetic conditions, playground, lavatory and facilities significantly enhanced students' enrolment. The current findings are synonymous with the study investigated by Taiwo, Oyesola and Adeogun (2016) which found that school building influenced student high enrolment in private universities in south-west, Nigeria and that the goal achievement education rests solely on the availability of physical facilities. Similarly, Todd's (2003) study found that availability of digital library contributed to students' high enrolment in higher institutions. The work of Fabunmi (2016) showed that good facilities appear to be an important preoccupation for students' enrolment, provided that other conditions are present that support a strong academic programme in the school. A growing body of research has linked students' enrolment and behaviours to the physical building conditions and overcrowding. Ademola, Babatunde and Ogundipe (2014) concluded that increase in students' enrolment is connected with the facilities provided in the school.

In line with the second research question of the study, which was based on students' graduation rate in Al-Hikmah University, findings reveal that $2009 / 2010$ produced the least number of graduating students at undergraduate level with a value of 107 students while 2015/2016 has the highest number of graduating students with a value of 874 students. At postgraduate level, findings show that 54 students graduated in the year 2014/2015 academic session while 50 students graduated in 2015/2016 academic session. Though there was a decrease in 2016/2017 as 43 students graduated. In 2017/2018, there was slight increase as the number of graduands rose to 64 while in 2018/2019, the graduation rate decreased drastically to 19 students. The foregoing findings corroborates the study conducted by Adeogun (2015) established that students' graduation assessment cannot be ignored because it is a vital determinant 
of school growth and development. The study investigated by Onasanya and Adegbija (2017) revealed that well sited school buildings with aesthetic conditions are key to high rate of graduation in higher educational institutions. Also, the current findings are in agreement with the work of Ileuma (2015) who concluded that availability of facilities increased both enrolment and graduation rate in higher institutions.

\section{CONCLUSION AND RECOMMENDATIONS}

It is a fact that enrolment and graduation rates are key important issues in education system. Based on the findings of the study, it can be concluded that there is need for Al-Hikmah University to build on the success recorded since the inception. The study recommends that:

1. To increase the students' enrolment, massive advertisement is needed. Specifically, there is need for constant advertisement on Television Stations, Radio Stations, Newspapers and other media outlets.

2. There is need for recruitment of agents to assist the university in sourcing for students that are yearning for admission. The agents to be recruited must be remunerated based on number of students they bring to the university; this will increase their recruitment drive.

3. The school fees need downward review so as to increase enrolment of students.

4. As it is been done in other private universities, there is need for contact offices to be established in Lagos State and Federal Capital City.

5. Additional facilities need to be put in place to increase the carrying capacity of the university.

\section{REFERENCES}

1. Ademola, O. Babatunde, W. \& Ogundipe, A. (2014). Students' enrolment into tertiary institutions in Nigeria. Computing Information System, Development, Informatics and Allied Research Journal, 5(3), 1-29.

2. Adeogun, A. A. (2001). Instructional Resources and School Effectiveness in Private and Public. JAOSEM, 1 (1), 113-122.

3. Ayodele, J. B. (2015). Educational system Analysis. Ibadan: Macmillan Nigeria Publisher Limited.

4. Clark, N. (2014) Public policy and technological change in Africa: Aspects of instructions and management capacity. Journal of Economic Studies, 27(1), 75-93.

5. Dada, J. O. (2017). Factors affecting women enrolment in construction education in Nigeria. Journal of Construction Project Management and Innovation, 7(Suppl. 1), 1893-1907.

6. Enagbonma, O., \& Osagiede, A. A. (2018). A mathematical model for estimating the ideal number of outsource academic staff for Private Universities in Nigeria. Journal of Advances in Mathematics and Computer Science, 1-11.

7. Fabunmi, F. (2016). The demand for higher education and institutional enrolment forecasting. Development of Science Research in Africa, 4 (1), 25-36. 
8. Harry, C. I. (2019). A historical attempt at the expansion of access through the establishment of private universities in Nigeria, 1999-2010. European Journal of Education Studies, 8(2), 22-36.

9. Ihugba, O. A., Ukwunna, J. C., \& Sandralyn, O. (2019). Government education expenditure and primary school enrolment in Nigeria: An impact analysis. Journal of Economics and International Finance, 11(3), 24-37.

10. Ileuma (2015) conducted study on managing educational facilities and students' enrolment in Nigerian Universities in South-West Nigeria. An International Multidisciplinary Journal, 9 (3), 1-10.

11. Musa, A., \& Bichi, A. A. (2019). Increasing access and students' enrolment in basic education: A challenge to quality education in Kano State, Nigeria. International Journal of Learning and Teaching, 11(4), 128-135.

12. Nwagu, C. C. (2014). Ensuring the quality of educational opportunity and excellency in Nigeria. Journal of Educational Issues, 2 (5), 12-23.

13. Ogbodo, C. M. (1995). Managing Educational Facilities in School. In: Peretomode V. F. (ed.) Introduction to educational administration, Planning and Supervision. Lagos: Joja Press.

14. Olutola, K. (2017). Gender equality in students' enrolment in Nigeria universities. A paper submitted to the Association of African Universities, Ibadan on the $12^{\text {th }}$ August, 2018.

15. Omitogun, O., Akanni, F. A., Longe, A. E., \& Balogun, A. (2017). Disaggregated government expenditure and education enrolment in Nigeria. Economics, 63(4), 309-326.

16. Omodero, C. O., \& Nwangwa, K. C. (2020). Higher education and economic growth of Nigeria: Evidence from co-integration and granger causality examination. International Journal of Higher Education, 9(3), 173-182.

17. Onasanya, R. \& Adedigba, K. (2017). Only 1 percent of Nigerian population in universities. Retrieved $7^{\text {th }}$ August, 2020 from https://www.premiumtimesng.com/

18. Oviawe, J. I. (2017). Fostering students' enrolment in technical education programmes through career guidance and occupational awareness. Education Journal, 6(4), 125-132.

19. Oyesola, G. O. (2000). Physical facilities and productivity in education. In Fagbamiyi E. O. \& Durosaro, D. O. (eds.) Education and Productivity in Nigeria. Ilorin: Haytee Press and Publishing.

20. Olaniyonu, F. (2016). Fundamental of system analysis in education. Lagos: Bolababy Publisher Stickhard, K. S. \& Maybee, K. (2016). Higher education and development. IIEP: UNESCO.

21. Rukayat, R. (2015). Education system in Nigeria. Retrieved $20^{\text {th }}$ August, 2020 from https://wenr.wes.org/2015/03/edu.ng

22. Taiwo, F. Oyeshola, K. \& Adeogun, U. (2016). Politics and development of tertiary institutions in Nigeria. International Journal of Educational Management, 5(6), 166-178.

23. Todd, J. (2003). School age population. Washington DC: Nested Press. 